\title{
Vaticanus Distigme-obelos Symbols Marking Added Text, Including 1 Corinthians 14.34-5
}

\author{
PHILIP B. PAYNE \\ Linguist's Software, 844 Alder St., Edmonds, WA 98020, USA. \\ Email: philip.b.payne@gmail.com
}

\begin{abstract}
The two-dot-plus-bar 'distigme-obelos' symbols in Vaticanus signal added text. Five characteristic features distinguish their obeloi from paragraphoi. Like scribe B's LXX obeloi, all eight distigme-obelos symbols mark the location of added text. A gap at the exact location of a widely recognised, multi-word addition follows every distigme-obelos except one with distinctive downward dipping strokes. The Vaticanus Gospels are so early that they have virtually no high stops, a feature older than even $\mathfrak{P}^{75}$. Consequently, they contain none of these additions, but the Vaticanus epistles have high stops throughout and contain their one distigme-obelos-marked addition, 1 Cor 14.34-5. Contemporaneous LXX G has corresponding distigmai.
\end{abstract}

Keywords: distigme, obelos, distigme-obelos, Vaticanus, 1 Cor 14.34-5, LXX G, $\mathfrak{D}^{75}$, $\bigcap^{32}$

\section{Introduction}

This article publishes for the first time all eight instances in codex Vaticanus B (henceforth, Vaticanus) where a distigme ${ }^{1}$ identifying a textual variant is combined with a bar that has five specific characteristics. ${ }^{2}$ It argues that just as bar-shaped obeloi in the Vaticanus prophets identify the locations of blocks of added text, so do all eight distigme-obelos symbols in the Vaticanus NT. Milne, Skeat and Canart ascribe each Vaticanus LXX book with obeloi and asterisks to the same scribe who penned the Vaticanus NT,

1 D. Parker, H. Houghton, T. Wasserman, M. Holmes, T. Brown, P. Canart, P. Andrist, P. Payne and classicist A. Kelly chose this name (plural, distigmai). For their reasons, see P. Payne and P. Canart, 'Distigmai Matching the Original Ink of Codex Vaticanus: Do They Mark the Location of Textual Variants?', Le manuscrit B de la Bible (Vaticanus graecus 1209): Introduction au fac-similé, Actes du Colloque de Genève (11 juin 2001), Contributions supplémentaires (ed. P. Andrist; Lausanne: Éditions du Zèbre, 2009) 199-226, at 199-200. The current article uses this now-conventional name and the corresponding Greek forms 'obelos', 'obeloi' and 'distigme-obelos' to be consistent with recent scholarly literature about these Vaticanus symbols. 
scribe B. ${ }^{3}$ On the line to the right of each distigme-obelos symbol - except one with a downward stroke from both dots and the bar, indicating a different hand - is a gap (henceforth, 'following gap') in the text at the exact location of a multi-word block of text widely recognised as not original, but added later (henceforth, 'added text'). Only the original scribe could have put these gaps in the text. The distigme at Luke $\mathbf{1 4 . 2 4}$ matches the original Vaticanus ink. Therefore, since obeloi mark the location of added text, their conjunction with a gap at the exact location of added text is most naturally explained if scribe B penned these symbols and left the following gap to mark where text was added.

It appears that all studies of distigmai in Vaticanus agree that distigmai correlate closely with the location of textual variants. ${ }^{4}$ Probability tests confirm this correlation to a high degree of reliability. ${ }^{5}$ Ever since Canart concluded that fifty-one distigmai match the apricot colour of the original Vaticanus ink on the same page and identified traces of original ink protruding from some evidently re-inked distigmai, ${ }^{6}$ there has been a growing acceptance that at least the original-ink-colour distigmai date to the fourth century and mark the location of textual variants. ${ }^{7}$

$3 \mathrm{H}$. Milne and T. Skeat, Scribes and Correctors of the Codex Sinaiticus (London: British Museum, 1938) 87-90; T. Skeat, 'The Codex Sinaiticus, the Codex Vaticanus, and Constantine', JTS NS 50 (1999) 583-625, at 604; P. Canart, 'Le Vaticanus graecus 1209: notice paléographique et codicologique', Le manuscrit B, 19-43, at 25.

4 As concluded by E. Gravely, 'The Relationship of the Vaticanus Umlauts to Family 1', Digging for the Truth: Collected Essays Regarding the Byzantine Text of the Greek New Testament: A Festschrift in Honor of Maurice A. Robinson (ed. M. Billington and P. Streitenberger; Norden, Germany: FYM, 2014) 54-72, at 54 and T. Wasserman, The Epistle of Jude: Its Text and Transmission (CBNTS 43; Stockholm: Almqvist \& Wiksell, 2006) 239.

5 Payne and Canart, 'Distigmai', 209-10 identify two chi-square test results, both showing that the probability of such a high correlation between original-ink-colour distigmai and $\mathrm{NA}^{28}$ textual variants occurring in random distribution is far less than 1 in 10,000.

6 Payne and Canart, 'Distigmai', 203-9, 214-15 identify protruding ink at 1469 A3 and 1501 B42. In both cases $\mathrm{NA}^{28}$ cites a variant. Original-ink-colour distigmai occur by each of the six columns in roughly even distribution: respectively, eight, nine, seven, seven, nine, eleven. Consequently, they defy any explanation of their distinctive apricot colour based on their position on the page.

7 Including W. Willker, 'Codex Vaticanus Graece 1209, B/o3: The Umlauts', www.willker.de/ wie/Vaticanus/umlauts.html; J. Miller, 'Some Observations on the Text-Critical Function of the Umlauts in Vaticanus, with Special Attention to 1 Corinthians 14.34-35', JSNT 26 (2003) 217-36; E. Epp, Junia: The First Woman Apostle (Minneapolis: Fortress, 2005) 18-19; Wasserman, Jude, 239; C. Amphoux, 'Codex Vaticanus B: les points diacritiques des marges de Marc', JTS NS 58 (2007) 440-66, at 447; P. Andrist, 'Le milieu de production du Vaticanus graecus 1209 et son histoire postérieure: le canon d'Eusèbe, les listes du IV siècle des livres canoniques, les distigmai et les manuscrits connexes', Le manuscrit B, 22756, at 240-52; Canart, 'Vaticanus graecus 1209', 42; A. Lavrinoviča, '1.Kor.14:34,35 Interpolācija?' (Master's Thesis, University of Latvia, 2012) 69-70; A. Forte, 'Observations on the 28th Revised Edition of Nestle-Aland's Novum Testamentum Graece', Biblica 94 (2013) 268-92, at 289-91; J. Shack, 'A Text Without 1 Corinthians 14.34-35? Not According to the 
Other surviving NT manuscripts contain a variant reading in over 92 per cent of these fifty-one distigme locations. ${ }^{8}$

This article begins by establishing the use of distigmai near the time of Vaticanus in the fourth- or fifth-century LXX G. It then provides evidence that scribe B repeatedly left comments explaining that obeloi signify added text. After analysing the eight distigme-obelos symbols in the Vaticanus NT, it argues from the form and function of their characteristic bars that it is highly improbable these eight bars are simply paragraphoi unrelated either to the distigme or to the added text at the exact point of the following gap.

The article concludes by providing an explanation why the Vaticanus Gospels do not include any of the blocks of added text their five distigme-obelos symbols mark, but the Vaticanus epistles do include the block of added text their one distigme-obelos marks. The contrast between the presence of high stops throughout the Vaticanus epistles and their virtually complete absence from the Vaticanus Gospels indicates that practically all the Vaticanus Gospels' text preceded the adding of high stops and so is earlier than the Vaticanus epistles' text. It is even earlier than $\mathfrak{P}^{75}$ 's text, which has high stops throughout. This vindicates scholarly judgement that the Vaticanus Gospels' text is earlier than its epistles' text. ${ }^{9}$ Its text is so early that it preceded all five of its distigme-obelos-marked additions, hence their omission from its Gospels.

This study demonstrates that scribe B was a careful textual critic who identifies 1 Cor $14.34-5$, the only Bible passage silencing women in the church, as added text. Vaticanus provides early and credible judgement in what is widely regarded as the most important NT manuscript that vv. 34-5 were not in the body text Paul's original letter, but are a later addition. This is important theologically since it offers a resolution to the notorious difficulty of reconciling vv. 34-5 with Paul's many affirmations of women in vocal ministry and their equal standing with men in Christ.

Manuscript Evidence', JGRChJ 10 (2014) 90-112, at 102 n. 45; and Gravely, 'Vaticanus Umlauts', 54 .

8 All but numbers 4, 35, 42 and 51 in Payne and Canart, 'Distigmai', 204-9. R. Swanson, New Testament Greek Manuscripts, Variant Readings Arranged in Horizontal Lines against Codex Vaticanus: 1 Corinthians (Wheaton, IL/Pasadena, CA: Tyndale House/William Carey, 2003) 125, 178, 211 and 257 lists variants for numbers 46, 47, 48 and 49 at 1 Cor 9.6-7; 11.28; 14.3; and 15.34.

9 E.g. S. Pisano, 'The Text of the New Testament', Bibliorum Sacrorum Graecorum Codex Vaticanus B: Prolegomena (Rome: Istituto Poligrafico e Zecca dello Stato, 1999) 27-41, at 40. 


\section{Does Any Manuscript near the Time of Vaticanus Contain Distigmai?}

The most extensive early hexaplaric manuscript known, the fourth- or fifthcentury codex Colberto-Sarravianus, ${ }^{10}$ called LXX G (henceforth, ' $G$ '), also marks the location of textual variants using distigmai. For example, the distigme at $\mathrm{G} 228$ B20 (Deut 15.11) marks a textual variant between G and the LXX (see Fig. 1). The distigme in the margin is at the exact point where $\mathrm{G}$ omits words that occur in

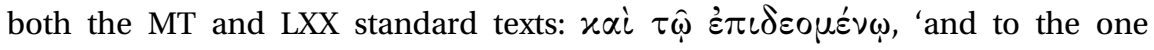
who is distressed'. It identifies where G text differs from the standard LXX text. Thus, like the Vaticanus distigmai, it marks the location of a Greek textual variant. $^{11}$

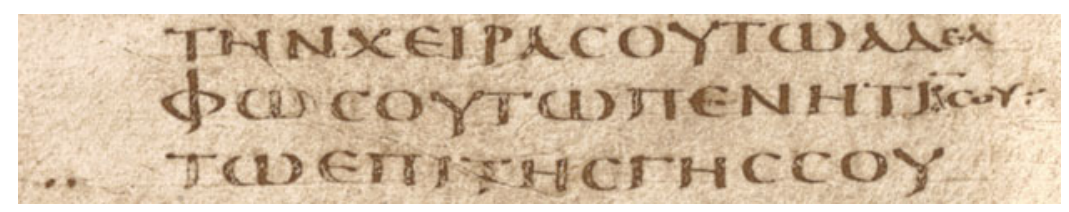

Figure 1. Distigme at LXX G 228 B20. Image made by the author from Vetus Testamentum graece: codicis Sarraviani-Colbertini quae supersunt in bibliothecis Leidensi, Parisiensi, Petropolitana phototypice edita (ed. H. Omont; Leiden: A. W. Sijthoff, 1897).

G's distigmai confirm that D. Parker was correct to reject C. Niccum's arguments that it is 'likely' the distigmai 'originated with Sepulveda ... Payne successfully vindicated his case [against Niccum's critique]'. ${ }^{12}$ They also confirm E. Gravely's case against 'the most recent (and only current) arguments for a late date for all the Vaticanus umlauts' by P. Head. ${ }^{13}$ Stark differences in ink

10 Explanatio signorum, quae in Septuaginta (ed. A. Rahlfs; Stuttgart: Württembergische Bibelanstalt, 1935).

11 Similarly, the distigme at G 219 B8 marks $\pi 0 \tau \varepsilon$ as an addition to both the standard LXX text and the MT. If the two dots were joined, the resulting line would be far shorter than any $\mathrm{G}$ obelos. G 273 A12's distigme marks text replacing the MT. G 144 A28 and 229 A15's distigmai function as obeloi.

12 D. Parker, 'Through a Screen Darkly: Digital Texts and the New Testament', JSNT (2003) 395411, at 408 n. 17. C. Niccum, 'The Voice of the Manuscripts on the Silence of Women: The External Evidence for 1 Cor 14.34-5', NTS 43 (1997) 242-55, at 245, n. 20. P. Payne and P. Canart, 'The Originality of Text-critical Symbols in Codex Vaticanus', NovT 42 (2000) 105-13, at 109 n. 25 and P. Payne, Man and Woman, One in Christ: An Exegetical and Theological Study of Paul's Letters (Grand Rapids: Zondervan, 2009) 235-7 rebut Niccum's arguments.

13 Gravely, 'Vaticanus Umlauts', 54-5 regarding P. Head, 'The Marginalia of Codex Vaticanus: Putting the Distigmai in their Place', presented to the SBL New Testament Textual Criticism Seminar, New Orleans, 2009. Cf. E. Gravely, 'The Text Critical Sigla in Codex Vaticanus' 
colour in the same Vaticanus distigme, such as 1409 B25, 1469 A3 and 1501 B42, ${ }^{14}$ are not compatible with Head's assertion that distigmai are all the product of the same process and of approximately the same date. Scribe B copied hexaplaric obeloi and asterisks, so may have also copied distigme use from a hexaplaric manuscript such as G, especially since the extensive parallels between these two manuscripts suggest they came from the same scriptorium. ${ }^{15}$

\section{Did Scribe B Understand that Obeloi Mark Added Text?}

Scribe B used obeloi extensively and explained that they mark added text. Vaticanus is the principal manuscript showing hexaplaric readings in Isaiah ${ }^{16}$ and also uses them in Zechariah, Malachi and Jeremiah. By the author's count, Vaticanus contains 121 obeloi but only twelve asterisks. ${ }^{17}$ This illustrates the LXX translators' far greater tendency to add than to omit text from the MT. Most obeloi are faint and appear to match the apricot colour of the original Vaticanus ink. Every Vaticanus LXX obelos is bar-shaped except four with two dots and a long bar $(\div)$, each marking text not in the MT. ${ }^{18}$ One of these four is in the middle of text (1016 C12 at Isa 14.23), ${ }^{19}$ so is properly assigned to scribe B.

Vaticanus explains what obeloi signify three times in Isaiah adjacent to an obelos: oน $\omega \beta^{\prime}$ ou $x^{\prime} \pi^{\prime} \varepsilon \beta \rho^{\prime}$ (oi $\omega \beta \varepsilon \lambda i \sigma \mu \varepsilon v o \iota$ ou $x \varepsilon i \tau \alpha \iota \pi \alpha \rho^{\prime}$ ¿ $\beta \rho \alpha i o \iota \varsigma$ ), 'the [lines] marked with an obelos contain [text] not in [the] Hebrew [text].$^{20}$ In addition, Canart judges the explanation ou $\chi^{\prime} \pi^{\prime} \varepsilon \beta \rho^{\prime}$ to be in the same ink as

(PhD diss., Southeastern Baptist Theological Seminary, 2009) 81-9, www.pbpayne.com/ wp-content/uploads/2010/03/Critique-of-Vaticanus-Marginalia-15Apr2010.pdf, gives a detailed critique of Head's argument.

14 Payne and Canart, 'Distigmai', 214-15, with a magnified photograph, Plate 8b.

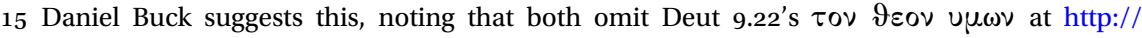
evangelicaltextualcriticism.blogspot.com/2010/02/putting-distigmai-in-their-place-payne_08. html. Both are biblical manuscripts of similar date with hexaplaric content and extensive text in double columns (all 306 surviving G pages and Vaticanus 625-893) on vellum by skilled calligraphers using similar letter-forms. Scholars identify Alexandria as the provenance of both G and Vaticanus. They share similar use of distigmai, bar-shaped and $\div$ shaped obeloi, asterisks, diplai, nomina sacra and spelling ( $\varepsilon \iota$ for $\iota)$.

16 Andrist, 'Le milieu', 242; Plate 4b shows both asterisks and obeloi. J. Ziegler, ed., Isaias (Septuaginta: Vetus Testamentum Graecum auctoritate Academiae Scientiarum Gottingensis editum 14; Göttingen: Vandenhoeck \& Ruprecht, 1983 ${ }^{3}$ ) 38-41 identifies B and $\mathrm{V}$ as the main group of hexaplaric witnesses for Isaiah.

17117 bar-shaped obeloi (Isaiah has ninety-two, Jeremiah nine, Zechariah eleven, Malachi five), $4 \div$ shaped obeloi in Isaiah, 6 asterisks each in Zechariah and Isaiah.

18 The $\div$ shaped obelos occurs by $1012 \mathrm{C} 9,1014 \mathrm{C} 15$ and $1016 \mathrm{C} 12$ (twice).

19 Ziegler, Isaias, 56 incorrectly writes that there are no obeloi in the text.

20 At Isa 51.23; 54.17; 60.14 and abbreviated ov $\chi^{\prime} \pi^{\prime} \varepsilon \beta \rho^{\prime}$ at Isa 36.22; Zech 8.2. Cf. Ziegler, Isaias, 56. Peter Gentry's 6 June 2015 email to the author identifies $\omega \beta \varepsilon \lambda \iota \sigma \mu \varepsilon \nu \circ \iota$ as the 
the original text of Vaticanus at $988 \mathrm{~A} 7,1034 \mathrm{~B} 31$ ( $\pi^{\prime} \varepsilon \beta \rho^{\prime}$ in original ink), 1046 A40, $1073 \mathrm{C} 36$ and $1074 \mathrm{~B} 17^{21}{ }^{21}$ locations with no obelos. Each signals text not in the MT. ${ }^{22}$ Their original apricot colour, their lack of obeloi, and the same explanation in apparently original ink with an obelos at $992 \mathrm{~A} 20,{ }^{23}$ make scribe B the most likely originator of the Vaticanus ou $x^{\prime} \pi^{\prime} \varepsilon \beta \rho^{\prime}$ abbreviations. All this indicates that scribe B knew enough about the Hebrew MT to mark where the LXX added text to the MT, even where Vaticanus' exemplar had no obelos. It also indicates that scribe B faithfully copied the exemplar without even adding obeloi.

The obelos was the standard symbol for spurious text in ancient Greek literature. $^{24}$ Indeed, it was its 'first and most important' text-critical symbol. ${ }^{25}$ F. Schironi argues it has 'a rather unequivocal meaning' so the reader knows that an obelised 'line is considered spurious, and this is an unambiguous piece of information' ${ }^{26}$ Basil (ca. 329-79), Hex. 4-5, identifies the obelos in the LXX as $\dot{\gamma} \vartheta \varepsilon \tau \dot{\eta} \sigma \varepsilon \omega \varsigma \sigma \dot{\mu} \mu \beta \circ \lambda \circ \nu$, a symbol of spurious text. Consequently, scribe B would understand that adding an obelos to a distigme would specify what kind of variant it marked, namely added text.

perfect medio-passive of $\partial \beta \varepsilon \lambda i \zeta_{\omega} \omega$. The OdysseaUBSU Greek font used throughout this article is available from www.linguistsoftware.com/lgku.htm.

214 June 2015 email to the author, 'Dans tous les endroits indiqués, l'encre, pâle, me semble la même que celle des passages non repassée.'

22 Respectively, Zech 1.19, 'my Lord'; Isa 35.9, 'and gathered'; Isa 46.1, 'exhausted, hungry'; Jer 8.7, 'wild'; and Jer 8.21, 'as of a woman in travail'.

23 Canart, 20 October 2015 email to the author, 'l'encre, très pâle, pourrait être celle de l'original'.

24 E. Turner, Greek Manuscripts of the Ancient World (London: University of London Institute of Classical Studies, $1987^{2}$ ) 38, 'obelos ... to indicate spurious text'; V. Gardthausen, Griechische Paleographie, vol. II: Die Schrift, Unterschriften und Chronologie im Altertum und im byzantinischen Mittelalter (2 vols.; Leipzig: Veit, 1911-13') II.413-14, 'zur Tilgung von Worten und Buchstaben ... Athetesen, durch einen Obelus', cites 'Diogenes Laert. 3,65-66, ỏ $\beta \varepsilon \lambda o ̀ s$

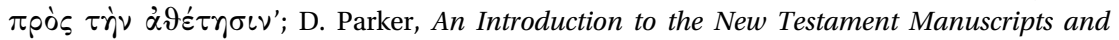
their Texts (Cambridge: Cambridge University Press, 2008) 192 explains the obelos as 'a symbol indicating a measure of uncertainty ... Nestle-Aland ... double square brackets around the text serve the same function ... (German text p. $7^{*}$; English text, p. 50*): they "indicate that the enclosed words, generally of some length, are known not to be part of the original [ursprunglichen] text."' N. de Lange, 'The Letter to Africanus: Origen's Recantation?', Papers Presented to the Seventh International Conference on Patristic Studies held in Oxford 1975, Part II (ed. E. Livingstone; StPatr 16; TU 129; Berlin: Academie-Verlag, 1985) 242-7, at 246, 'spurious'; F. Schironi, 'The Ambiguity of Signs: Critical $\Sigma$ HMEIA from Zenodotus to Origen', Homer and the Bible in the Eyes of Ancient Interpreters (ed. M. Niehoff; Leiden/ Boston: Brill, 2012) 87-112, esp. 89, 95, 103, 108, 'athetesis', 'spurious', 'addition'. LSJ p. 1196 s.v. ỏß $\beta \lambda o ́ \varsigma$ II 'a critical mark to point out that a passage was spurious', p. 31 s.v. $\dot{\alpha} \vartheta \varepsilon \tau \dot{\varepsilon} \omega$ II 'Gramm., reject as spurious'.

25 L. D. Reynolds and N. G. Wilson, Scribes and Scholars: A Guide to the Transmission of Greek and Latin Literature (Oxford: Oxford University Press, $\left.2013^{4}\right) 11$.

26 Schironi, 'Ambiguity', 103. 


\section{The Eight Vaticanus Distigmai Adjacent to a Characteristic Bar}

Eight bars in the Vaticanus NT adjacent to a distigme correspond in shape to scribe B's LXX obeloi but are graphically different in two respects from the Vaticanus paragraphoi that occur at random adjacent to a distigme. First, they protrude into the margin, ${ }^{27}$ on average, $3.0 \mathrm{~mm}$ compared to a sharply contrasting $1.6 \mathrm{~mm}$ for the twenty undisputed paragraphoi. Their greater extension into the margin brings them closer to the adjacent distigme, associating them with the standard Vaticanus symbol marking the location of textual variants. The characteristic bar adjacent to a distigme at the interface of 1 Cor 14.33 and 34 extends $3 \mathrm{~mm}$ into the margin. In contrast, the seventy-five other bars in 1 Corinthians extend, on average, $2 \mathrm{~mm}$ into the margin, and only one of these seventy-five extends $3 \mathrm{~mm}$ into the margin $\left(1475\right.$ B29). ${ }^{28}$ Greater extension into the margin is their primary graphic distinction, but they also average $4.7 \mathrm{~mm}$ long compared to the remaining twenty bars' $3.6 \mathrm{~mm}$ average length. Thus, not only do they extend on average almost twice as far into the margin as these twenty undisputed paragraphoi, they are, on average, almost one third longer, as the characteristic bars near paragraphoi in Figs. 2-4 illustrate.

Of the twenty-eight bars following a distigme, only these eight combine noticeably further extension into the margin with noticeably greater length.

The function of the eight bars in question also evidently differs from paragraphoi. Each occurs at the location of a widely acknowledged block of added text. The $\mathrm{NA}^{28}$ apparatus identifies a multi-word textual variant at least three words long at each of these eight locations. In each case, at least two words are completely different from the Vaticanus text, not just different forms of the same word. 'Multi-word variant' entails this characteristic henceforth.

$\mathrm{NA}^{28}$ 's apparatus is an appropriate basis for assessing whether distigme-obelos symbols are text-critical symbols since $\mathrm{NA}^{28}$ identifies 'variants of text-historical relevance'. ${ }^{29}$ Multi-word additions have important text-historical relevance. Scribe B marked added text in the LXX prophets with obeloi and explanations

27 'The margin' is at the far-left edge of letters on the margin, excluding $T Y \phi$ and $\nsucc$, whose vertical stroke is at the margin, and $\boldsymbol{X}$, which straddles the margin. The VaticanusLSU font is available from www.linguistsoftware.com/ntmssu.htm.

28 Excluding the bar at $1470 \mathrm{~B} 2$ since it is noticeably lower than all the other eight paragraphoi on 1470-1; it does not match the surrounding text's ink colour or stroke thickness, but rather the colour, graininess and stroke thickness of the ink of the adjacent, later, marginal addition; and, unlike every other paragraphos bar in 1 Corinthians, it does not underscore the first letter of its line. Contrast the paragraphos five lines later, at $1470 \mathrm{~B} 7$, that crosses a $\phi$ 's descender, just as paragraphoi cross the descender of all eight adjacent $\mathrm{s}(1242 \mathrm{~B}, 1259 \mathrm{C}, 1260 \mathrm{C}, 1262 \mathrm{~B}$, $1264 \mathrm{~B}, 1271 \mathrm{C}, 1273 \mathrm{~A}, \mathrm{~B})$ and all twelve adjacent ps (1239C, $1246 \mathrm{~B}, \mathrm{C}, 1247 \mathrm{~A}, 1249 \mathrm{~B}, 1256 \mathrm{~B}$, $1257 \mathrm{~A}, 1262 \mathrm{~A}, 1270 \mathrm{~A}, 1272 \mathrm{~A}, 1273 \mathrm{C}, 1274 \mathrm{~B})$ in Matthew.

$29 \mathrm{NA}^{28}, 49^{*}$. 


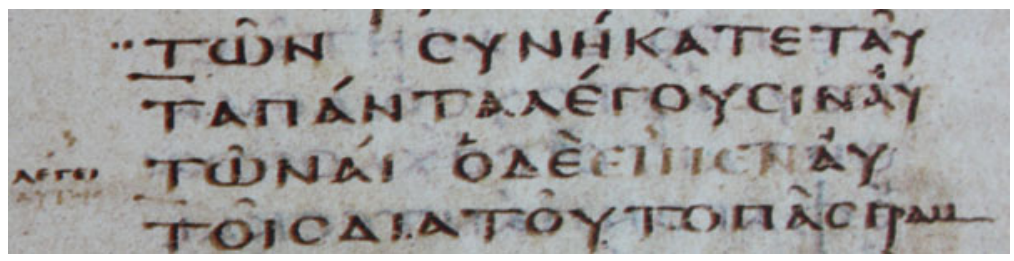

Figure 2. Matthew 13.51. Photograph by author.

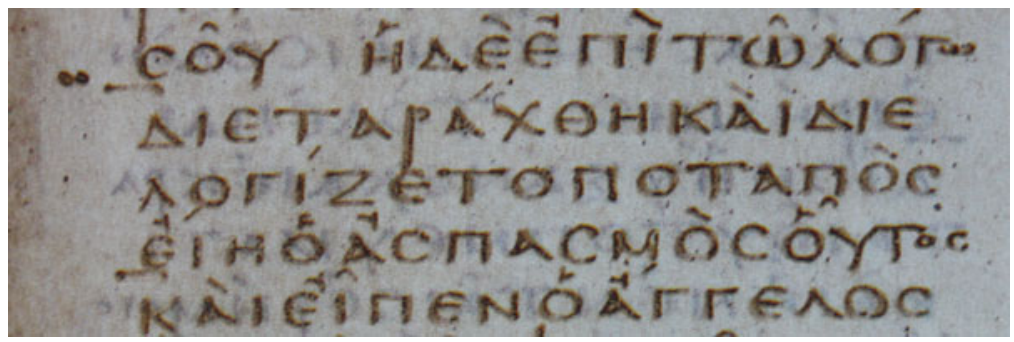

Figure 3. Luke 1.28-9. Photograph by author.

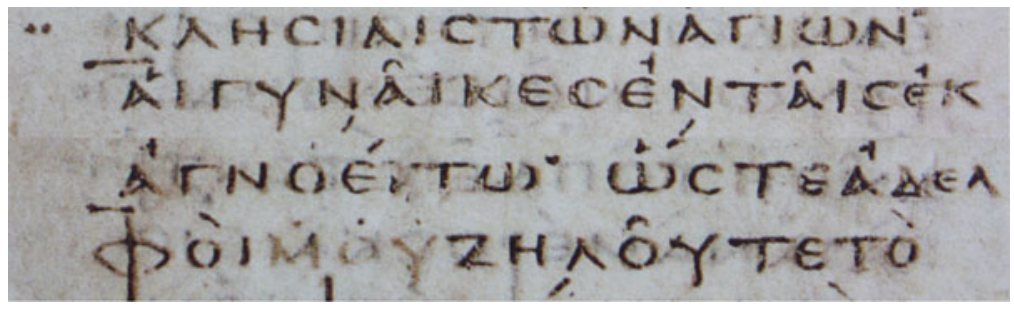

Figure 4. 1 Corinthians 14.33-4 and 38-9. Photographs by author.

that text was added. This proves he or she ${ }^{30}$ regarded blocks of added text as significant. B. Ehrman, as others, argues that 'even readings that are not attested in the fragmentary remains of the ante-Nicene age ... are by and large best understood as deriving from documents of the first three centuries ... The vast majority of all

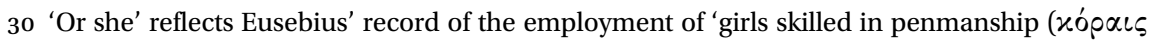

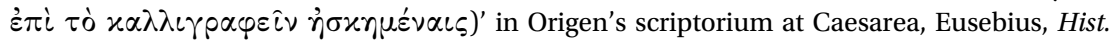
eccl. 6.32.2 (trans. J. Oulton, LCL, 1957) II.68-69. Similarly, Gerontius, Life of Melania 26 praises the calligraphic copying $(\kappa \alpha \lambda \lambda \iota \gamma \rho \alpha \varphi \circ v \sigma \alpha)$ of Melania the Younger. W. Doerpfeld and H. Hepding, Die Arbeiten zu Pergamon 1908-1909, vol. II: Die Inschriften, Mitteilungen des kaiserlich deutschen archäologischen Instituts, Athenische Abteilung 35 (1910) no. 20 identifies an inscription in Pergamum of a girl who wins a contest in $x \alpha \lambda \lambda \iota \gamma \rho \alpha \varphi i \alpha$. For more evidence, see K. Haines-Eitzen, The Gendered Palimpsest: Women, Writing, and Representation in Early Christianity (Oxford: Oxford University Press, 2012) 29-31 and 41-52. 
textual variants originated during ... the second and third centuries. ${ }^{31}$ This highlights the value of the $\mathrm{NA}^{28}$ apparatus for identifying early textual variants.

Following all eight distigmai adjacent to a characteristic bar, except the one whose downward dipping strokes indicate that a different scribe penned it, there is a gap either in the middle or at the end of the line of text at the exact location of a multi-word, widely acknowledged block of added text. By contrast, a gap occurs in only twelve of the twenty lines following a distigme adjacent to an undisputed paragraphos (6o per cent). ${ }^{32}$ Thus, both their characteristic form and apparent function distinguish these eight bars from paragraphoi and support viewing them as distigme-obelos symbols. The following analysis, however, refers to them neutrally as 'characteristic bars' until concluding that they are distigme-obelos symbols.

Following five of the seven apparently original characteristic bars, scribe B left a mid-line gap at least one letter wide at the exact location where other manuscripts add text. This far exceeds the average in Matthew of a correspondingly wide, mid-line gap only once every 23.5 lines of text. ${ }^{33}$ The other two bars are at the location of a block of added text at a gap at the end of a line that is at least one letter shorter than the average line length in that column.

Following are images of all eight distigmai adjacent to a characteristic bar (Figs. 5-12). Each figure's title gives that passage's verse reference and its Vaticanus page number and column. The triangle in each image identifies the exact location of widely recognised, added text. After each image are the added text and the manuscripts $\mathrm{NA}^{28}, \mathrm{NA}^{27}$, and/or Swanson lists with this addition or providing evidence of it.

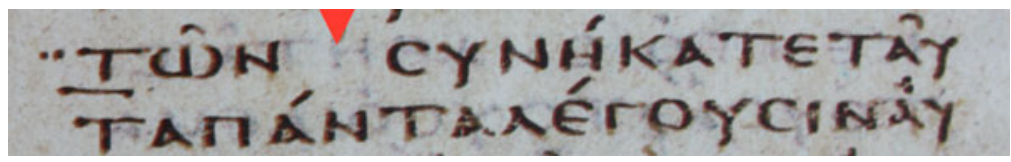

Figure 5. Matthew 13.511253 B. Photograph by author.

31 B. Ehrman, The Orthodox Corruption of Scripture: The Effect of Early Christological Controversies on the Text of the New Testament (Oxford: Oxford University Press, $2011^{2}$ ) 33. Cf., similarly, E. Colwell, 'The Origin of Texttypes of New Testament Manuscripts', Early Christian Origins: Studies in Honor of Harold R. Willoughby (ed. A. Wikgren; Chicago: Quadrangle, 1961) 128-38, at 138 and B. Aland, 'Die Münsteraner Arbeit am Text des Neuen Testaments und ihr Beitrag für die frühe Überlieferung des 2. Jahrhunderts: Eine methodologische Betrachtung', Gospel Traditions in the Second Century: Origins, Recensions, Text, and Transmission (ed. W. Petersen; Notre Dame/London: University of Notre Dame, 1989) 5570, at 65, 'Fast alle Varianten, die in den Papyri vorkommen, waren vorher schon aus späteren Handschriften bekannt.'

32 Eight have no gap: 1342 C, 1345 B, 1361 A, 1401 B, 1442 C, 1504 B, 1505 B26, 1505 B33. Nine have a mid-line gap: 1237 B, 1268 A, 1280 C, 1301 B, 1365 A, 1403 A, 1428 C, 1470 A, 1500 C. Three have a line-ending gap: $1262 \mathrm{C}, 1403 \mathrm{~B}, 1460 \mathrm{~B}$.

33 Namely gaps $0.32 \mathrm{~cm}$ or longer in 228 of the 5343 Vaticanus lines in Matthew. 


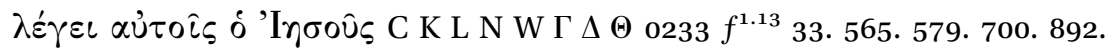
1241. $1424 \mathfrak{M}$ f h q sy $^{\text {c.p.h }}$ bo $^{\text {mss }}$ (a vg ${ }^{\text {mss }}$ mae)

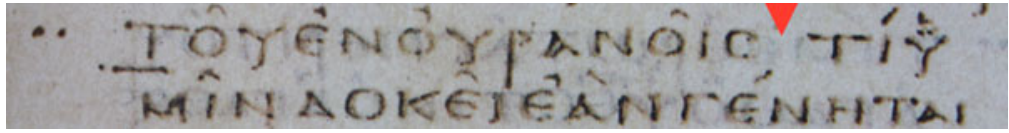

Figure 6. Matthew 18.111259 A. Photograph by author.

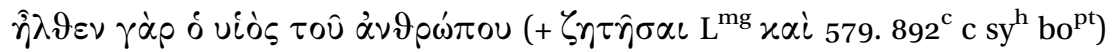

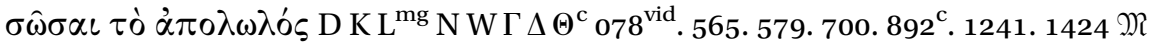
lat sy ${ }^{\text {c.p.h }}$ bo $^{\text {pt }}$

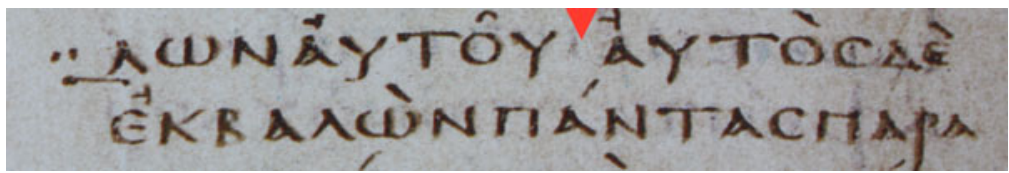

Figure 7. Mark 5.40 1284 C. Photograph by author.

ó $\delta \dot{\varepsilon}{ }^{\prime} \mathrm{I} \eta \sigma o u \varsigma^{34} \mathrm{M} \Phi f^{1} 124 p c \mathrm{sy}^{\mathrm{h}^{* *}}$

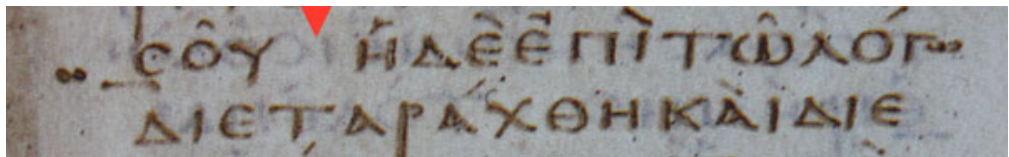

Figure 8. Luke 1.281305 A. Photograph by author.

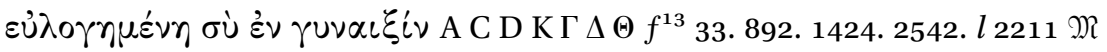
latt sy bo ${ }^{\mathrm{mss}}$; Eus

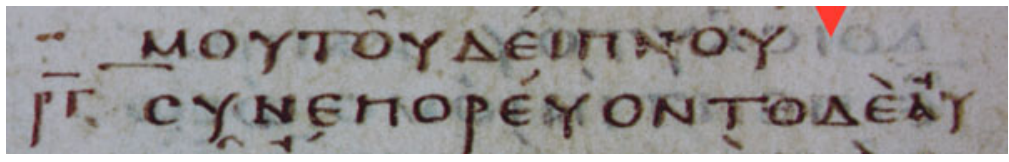

Figure 9. Luke 14.24-5 1332 C. Photograph by author.

34 B. Metzger and B. Ehrman, The Text of the New Testament: Its Transmission, Corruption, and Restoration (New York: Oxford University Press, 2005 ${ }^{4}$ ) 86-7 conclude that $f^{1}$ text is early: 'Textual analysis of the Gospel according to Mark indicates that the type of text preserved in $\left[f^{1} \ldots\right]$ appears to go back to the type current in Caesarea in the third and fourth centuries.' 


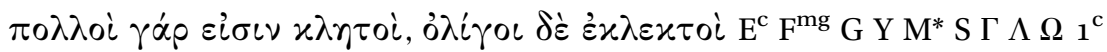
$118^{\mathrm{c}} f^{13} 2.28^{\mathrm{c}} .579 .700 .892^{\mathrm{mg}} .1071 \mathrm{al}$

Canart confirmed that the Luke $\mathbf{1 4 . 2 4}$ distigme matches the colour of the original Vaticanus ink. ${ }^{35}$

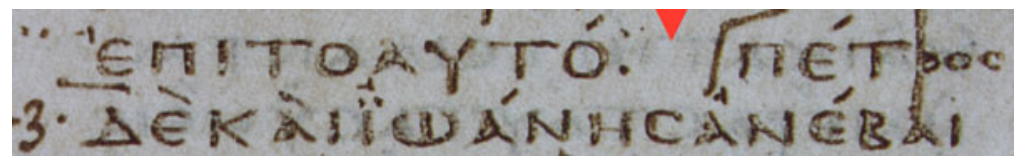

Figure 10. Acts 2.471385 B. Photograph by author.

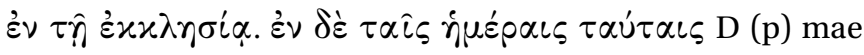

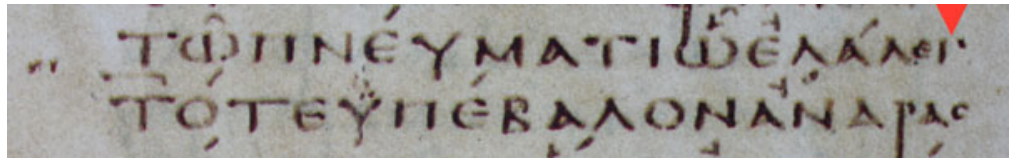

Figure 11. Acts 6.101390 A. Photograph by author.

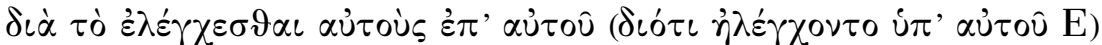

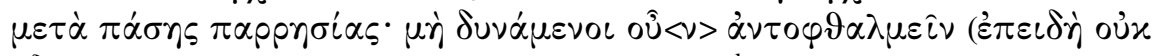

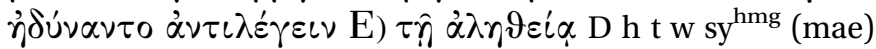

Acts 6.10 is the only one of these eight whose following line of text contains no noticeable gap. Both dots and the bar have downward strokes that are strikingly different from the other seven and distinguish it from the handwriting of scribe B. Consequently, it is highly doubtful this distigme and characteristic bar were in the original text. Furthermore, the added text is not as memorable as any of the other seven. Pamphilus and Eusebius circulated Origen's edited LXX text with obeloi and asterisks extensively in Palestine in the fourth century, so its readers, and any reader familiar with the obelos, including the obeloi in the Vaticanus prophetic books, would know that the obelos identifies the location of added text. ${ }^{36}$ Presumably, one such scribe or reader understood that a distigme plus an obelos-shaped characteristic bar marks added text and inserted this one at Acts 6.10 to mark that another manuscript adds text here.

35 Payne and Canart, 'Distigmai', 203-5 and 223-5. P. Payne, 'Fuldensis, Sigla for Variants in Vaticanus, and 1 Cor $14.34-5$ ', NTS 41 (1995) 240-62, at 253 incorrectly omitted it because in the only colour facsimile available to him then, Novum Testamentum e Codice Vaticano Graeco 1209 (Codex B) tertia vice phototypice expressum (Vatican: Bibliotheca Apostolica Vaticana, 1968) 98, it is red, not the original apricot colour.

36 H. Swete, 'Septuagint', ISBE (1915) Iv.2726. 


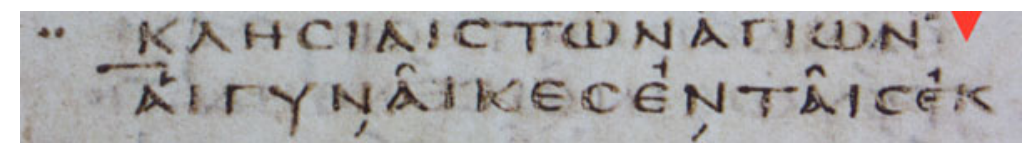

Figure 12. 1 Corinthians 14.33-4 1474 A. Photograph by author.

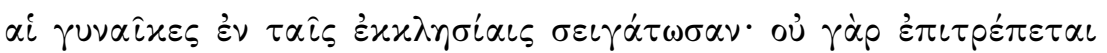

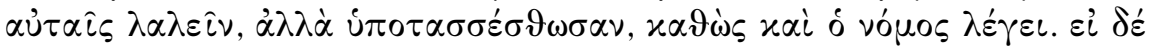

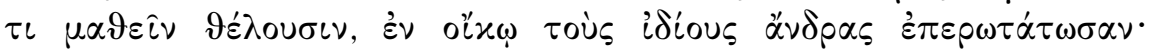

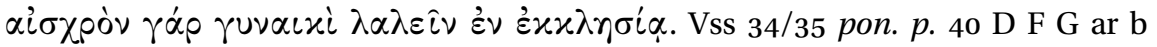
$\operatorname{vg}^{\mathrm{ms}}$; Ambst ' [- Straatman $c j$. D. Parker observes, 'Such variation in positioning often indicates an interpolation. ${ }^{37}$

If this distigme had indicated a transposition to the 'Western' location, there should also have been a distigme after v. 40 to indicate the corresponding variant there - but there is no distigme after v. 40. In any event, no other Vaticanus distigme plus characteristic bar occurs where there is a transposition within a passage. They all mark the location of multi-word additions, just like scribe B's obeloi in the Vaticanus prophetic books do. Consequently, this distigme plus characteristic bar far more appropriately identifies the addition of 14.34-5 than a transposition.

Should one trust scribe B's distigme-obelos marking 14.34-5 as added text? $\mathrm{NA}^{28}$ and manuscript evidence confirms a block of added text at the gap after every other scribe $\mathrm{B}$ distigme-obelos. To judge from the range of manuscripts reflected in those textual variants and original-ink-colour distigme variants and by the Vaticanus Gospel's early text, scribe B had access to far more early manuscript text than is now extant, enough to trust scribe B's judgement on $14.34-5 .{ }^{38}$

Transcriptional probability also argues that these verses' differing locations result from a marginal gloss, not transposition. 'The reading which can most easily explain the derivation of the other forms is itself most likely the original. ${ }^{39}$ No Pauline manuscript transposes any other passage nearly this large

37 Parker, Introduction, 272, 276. 'Gloss', however, avoids misunderstanding since some writers define 'interpolation' as deliberate polishing of the body text, but a 'gloss' as text written in the margin and later inserted into the text by copyists, as seems more likely here.

38 E.g. the wide range of manuscripts that represent variants marked by distigmai matching the colour of the original ink of Vaticanus that are listed in Payne and Canart, 'Distigmai', 204-8 and 214-15.

39 K. Aland and B. Aland, The Text of the New Testament: An Introduction to the Critical Editions and to the Theory and Practice of Modern Textual Criticism (trans. E. Rhodes; Leiden/Grand Rapids: Brill/Eerdmans, 1989 ${ }^{2}$ ) 276; Metzger and Ehrman, The Text, 300, 'Perhaps the most basic criterion for the evaluation of variant readings is the simple maxim, "choose the reading that best explains the origin of the others".' 
this far without an obvious reason. ${ }^{40}$ The most detailed attempt to find long transpositions in 'Western' manuscripts identifies only three instances. The longest moves a seven- or eleven-word benediction three verses forward for the obvious reason, to make 'an apt conclusion to the letter'. ${ }^{41}$ A thirty-six- to fortyword transposition five verses away with no obvious reason is unprecedented in any Pauline manuscript. It was conventional, however, for scribes to copy text in the margin, including reader comments, into the body text, as U. Schmid has shown. ${ }^{42}$ Vaticanus itself exemplifies this convention. Seventeen of its twenty instances of readable small uncial text in the margins of Matthew appear in the body text of most later manuscripts. ${ }^{43}$ Something conventional is far more likely to occur than something unprecedented. One early copyist apparently inserted vv. 34-5 from the margin into the text after v. 40, which gave rise to their 'Western' location. Another early copyist apparently inserted vv. 34-5 after v. 33, which gave rise to their usual location. ${ }^{44}$ This is the only explanation of this text's two locations congruent with common scribal practice. A marginal gloss far better explains both locations of vv. 34-5 than does an unprecedented transposition for no obvious reason. It is doubtful that vv. 34-5 could fit in a papyrus margin if written in Paul's 'large hand'. ${ }^{45}$

At least sixty-two textual studies argue that $14.34-5$ is a later addition. ${ }^{46}$ J. Fitzmyer notes that 'the majority of commentators today' regard vv. 34-5 as a

40 The different endings of Romans best explain the different locations of its doxology: at 16.25-7, after $\mathbf{1 4 . 2 3}$ and after 15.33, as argued by Parker, Introduction, 270, 272, 'there is compelling evidence that fourteen and fifteen chapter forms existed ... the Doxology is evidently a concluding formula', H. Gamble, Jr., The Textual History of the Letter to the Romans: A Study in Textual and Literary Criticism (SD 42; Grand Rapids: Eerdmans, 1977) and, particularly insightful, L. Hurtado, 'The Doxology at the End of Romans', New Testament Textual Criticism: Its Significance for Exegesis. Essays in Honour of Bruce M. Metzger (ed. E. Epp and G. Fee; Oxford: Clarendon, 1981) 185-99.

41 J. J. Kloha, 'A Textual Commentary on Paul's First Epistle to the Corinthians' (PhD diss., The University of Leeds, 2006) 549.

42 U. Schmid, 'Conceptualizing “Scribal” Performances: Reader's Notes', The Textual History of the Greek New Testament: Changing Views in Contemporary Research (ed. K. Wachtel and M. Holmes; Atlanta: SBL, 2011) 49-64, at 58, 'The inclination of scribes, at least in the view of the ancients, seems to have been toward the inclusion of marginal material into the main text.'

43 Each of these seventeen is in $\mathrm{NA}^{28}$ 's body text and in $\mathfrak{M}$ according to $\mathrm{NA}^{28}$.

44 As argued by G. Fee, The First Epistle to the Corinthians (NICNT; Grand Rapids: Eerdmans, 1987) 699-708 and God's Empowering Presence: The Holy Spirit in the Letters of Paul (Peabody, MA: Hendrickson, 1994) 272-81.

45 Gal 6.11; 2 Thess 3.17, pace E. Ellis, 'The Silenced Wives of Corinth (I Cor. 14,34-5)', Essays in Honour of Bruce M. Metzger, 213-20, at 219.

46 Payne, Woman, 226-67, cites fifty-five textual studies arguing this and analyzes seven external and nine internal evidences these verses are a later addition. 
later addition. ${ }^{47} \mathrm{~K}$. Haines-Eitzen affirms this of '[n]early all scholars now' ${ }^{48}$ Verses 34-5 silence women in church three times without any qualification. Chapter 11, however, guides how women should prophesy, and chapter 14, vv. 5, 24 (3x), 26 and 31 affirm 'all' speaking in church. Popular resolutions of this apparent contradiction limit 14.34-5's demand for silence only to disruptive chatter or, recently contrived, only to judging prophecies. These resolutions should be rejected since they permit speech v. 35 prohibits, namely asking questions from a desire to learn. In light of substantial evidence that vv. 34-5 were originally a marginal gloss and no evidence that any other block of text was added at this gap, ${ }^{49}$ these verses are the obvious candidate for the multi-word addition signalled by this distigme plus characteristic bar.

In six of the eight cases under discussion, the addition is to the line of text the bar underscores. Paragraphoi also underscore a line of text when the paragraph break occurs within that line. When a paragraph ends at the end of a line, a paragraphos underscores that line, marking the interface between the paragraphs. Likewise, two characteristic bars adjacent to distigmai underscore the last line of the original text and mark the interface between original text and a later addition. Luke 14.24 ends with a five-letter gap (see Fig. 9). The characteristic bar marks the interface between the original text and the later addition, 'For many are called but few are chosen.' Similarly, the two-letter gap compared with the next line ${ }^{50}$ at the end of 1 Cor 14.33 marks the interface between the original text and the widely recognised addition, 'Let women be silent in the churches ... for it is a disgrace for a woman to speak in church' (vv. 34-5) (see Fig. 12). A line preceded by a bar but followed by a distigme also separates John 7.52 from John 8.12 and marks the interface between the original text and the Pericope Adulterae.

All eight additions are arguably important theologically ${ }^{51}$ and include some of the passages most widely regarded as later additions: 'Jesus said to them' (Matt

47 J. Fitzmyer, First Corinthians (AB; New Haven: Yale, 2008) 530, citing twenty scholars, including, Cope, Delling, Fuller, Keck and Roetzel.

48 Haines-Eitzen, Palimpsest, 62.

49 The addition of $\delta \iota \delta \alpha \sigma \varkappa \omega$ is before the high stop, so precedes this gap, is not a multi-word addition, is not listed in $\mathrm{NA}^{28}$, and is apparently in no Greek manuscript before the ninth century. Furthermore, since its earliest occurrences are in 'Western' texts, it is doubtful that any scribe would have noted the addition of $\delta \iota \delta \alpha \sigma \varkappa \omega$ but not the far more obvious and noteworthy transposition of vv. 34-5.

50 The gap in the preceding line after $\varepsilon \varkappa$ is the result of the normal pattern throughout all thirtysix Vaticanus occurrences of the word $\varepsilon \varkappa \varkappa \lambda \eta \sigma \iota \alpha$ in Romans-2 Corinthians of only breaking either after $\varepsilon \chi$ (nine times, Rom 16.1; 1 Cor 1.2; 11.18; 14.5, 12, 33, 34; 2 Cor 8.1, 18) or after $\varepsilon x \varkappa \lambda \eta$ (six times, 1 Cor 11.16; 16.1; 2 Cor 8.19, 24; 11.28; 12.13), not anywhere else in the word. The breaks after $\varepsilon \chi$ in 1 Cor 14.5 (1473 A17) and 2 Cor 8.1 (1482 C14) leave a similar gap to that at 1 Cor 14.33 (1474 A19). Similar gaps are required in order to keep $\varepsilon \varkappa \varkappa \lambda \eta \sigma i \alpha$ together on one line at 1 Cor 7.17 (1466 C22); 12.28 (1472 B2); and 14.35 (1474 A31).

51 This does not imply that these are the only theologically important variants or that they follow a particular thread theologically. 
13.51), 'For the Son of Humanity came to save the lost' (Matt 18.11), 'but Jesus [with an article]' (Mark 5.40), 'Blessed are you among women!' (Luke 1.28), 'For many are called but few are chosen' (Luke 14.24), 'in the church. In those days' (Acts 2.47), 'Because it was to convict them concerning him with all boldness, since they were not able to face the truth directly' (Acts 6.10), and 'Let women be silent in the churches ... for it is a disgrace for a woman to speak in church' (1 Cor 14.34-5). The content of the addition is easily memorable in every case except the one with distinctive downward strokes at Acts 6.10. Scribe B, who also marked text the LXX added to the MT with similarly shaped obeloi, was apparently aware of these seven memorable NT additions, left a gap at the exact point they begin, and highlighted their location with a distigme and characteristic bar.

\section{Are These Characteristic Bars Paragraphoi or Obeloi, or Do They Have a Dual Function?}

C. Niccum writes that the bars following distigmai 'date to the fourth century' but are paragraphoi, not obeloi. ${ }^{52} \mathrm{He}$, Miller and Shack, although acknowledging that distigmai mark the location of textual variants, deny that there is any association between any bar and the adjacent distigme, and they deny that either these bars or the following gap mark the location of added text. ${ }^{53}$ Shack asserts that it 'is only a coincidence' that these bars are followed by gaps that always occur at the exact location where multi-word blocks of text were added. ${ }^{54}$

Even if there were no graphic differences between these eight bars and paragraphoi, their combination with distigmai could signal a more specific purpose just as other combined symbols do in Vaticanus. For example, a baseline dot functions like a comma at $1474 \mathrm{~A} 1$ and 36 , but added to a high stop it signifies a section break at 1474 B4. Similarly, a short slash descending from left of the middle of a paragraphos specifies a section or book break. ${ }^{55}$ Although their component parts individually convey distinct meanings, together these composite symbols convey a specific meaning that incorporates some of the meaning of both. Similarly, scribe B may have combined these distigmai with bars to convey a specific meaning.

There are, however, graphic differences between these eight bars and the other twenty bars adjacent to a distigme. All eight combine noticeably greater extension into the margin with noticeably greater length than the other twenty. Functionally also, all eight mark the location of widely acknowledged, multiword, added text, which is the purpose of obeloi. This extraordinarily consistent pattern supports the identification of these characteristic bars as obeloi.

52 Niccum, 'Voice', 244-5.

53 Niccum, 'Voice', 244-5; Miller, 'Observations', 217-24.

54 Shack, 'A Text', 102.

55 For example, 1463 B9, 1477 A6, 1483 C9, 1498 C22, 1516 A9. 
There are various possible relationships between the eight characteristic bars and obeloi and/or paragraphoi. Some of these blocks of added text occur at a natural paragraph break. Four of the seven gaps coincide with a paragraph break in $\mathrm{NA}^{28}$, and three with a paragraph break in the UBS ${ }^{5}{ }^{56}$ Only the gap at the interface of 1 Cor 14.33 and 34 is in the middle of an $\mathrm{NA}^{28}$ and $\mathrm{UBS}^{5}$ sentence. A. Lavrinoviča concluded, however, that every manuscript up to the twelfth century has a break at the beginning of v. 34, with the possible exception of the ambiguous $P^{123} \cdot{ }^{57}$ This $\mathrm{NA}^{28}$ and $\mathrm{UBS}^{5}$ paragraph break, therefore, is not where virtually any early scribe understood it should be. Vaticanus has a high stop after v. 33, and all early 'Western' Greek text scribes treat vv. 34-5 as a unit. Scribe B may have even regarded all seven gaps as occurring at a paragraph break. Or scribe B may have positioned the first three characteristic bars in the normal paragraphos location because they are all at natural paragraph breaks, then retained the same position for the others to keep them consistent.

By extending these eight bars on average almost twice as far into the margin as the other twenty bars following a distigme, ${ }^{58}$ scribe B associated the bar with the distigme marking the location of a textual variant. The obelos shape of the long bar and each gap at the exact location of a block of widely acknowledged added text strongly indicate that the bar does not function merely as a paragraphos, but also or especially as an obelos.

Four factors explain why scribe B did not simply use the usual LXX obelos position entirely in the margin to mark these blocks of text added to the NT. First, that position had already been taken by the customary Vaticanus distigme marking where these Greek variants occur. Second, this Vaticanus LXX obelos position marks text actually in Vaticanus as added, but the added words are not in the Vaticanus NT text, except in the last case.$^{59}$ Third, that obelos position marks differences between the LXX and MT, not between Greek texts. Fourth, readers associated hexaplaric marginal symbols with the LXX, not the NT.

A dual purpose of (1) marking the location of added text (2) at a paragraph break would explain the paragraphos position of the NT obeloi. An additional benefit (or alternative explanation) of this position is that putting an obelos below and to the right of a distigme is a logical way to specify the location of a specific kind of textual variant, the same kind scribe B's obeloi identify in the LXX, blocks of added text.

56 Matt 13.51; 18.11 ( $\mathrm{NA}^{28}$ only); Luke 14.24/25; Acts 2.47, the last two with old section numbers.

57 Lavrinoviča, '1.Kor.14:34.35', 38-64.

58 See above, pp. 610-11.

59 See above, pp. 612-18 and below, pp. 621-3. 


\section{How Strong is the Evidence that These Eight Bars are not Simply Paragraphoi?}

What is the statistical probability that in a random distribution all eight characteristic bars following distigmai would be at the location of a textual variant at least three words long in manuscripts cited in $\mathrm{NA}^{28}$ 's apparatus? Using Matthew as a conservative baseline, the probability that all eight Vaticanus lines would coincide with the location of a multi-word variant listed in $\mathrm{NA}^{28}$ is 1 in $31.8^{8}=1,045,723,722,517 .{ }^{60}$

Since distigmai mark the location of textual variants, however, lines following distigmai in Vaticanus are more likely to coincide with textual variants, including multi-word variants, than random lines are. So, this author compared the occurrence of multi-word variants at these eight distigmai adjacent to characteristic bars (eight of eight) to the twenty distigmai adjacent to undisputed paragraphoi (two of twenty). ${ }^{61}$ The standard probability test shows that the likelihood of such a stark difference occurring at random is far less than one in 10,000. ${ }^{62}$ This is over 500 times greater than the threshold needed to reject the null hypothesis. In this case, the null hypothesis is that characteristic bars adjacent to distigmai do not correlate with multi-word textual variants. This test result justifies distinguishing the eight characteristic bars from paragraphoi.

Furthermore, a gap follows all seven apparently original distigme-obelos symbols at the exact point where a multi-word addition begins. This identifies their location over sixteen times more precisely than simply somewhere in the line. ${ }^{63}$

All this shows to a high degree of probability that these characteristic bars are not simply paragraphoi that merely by chance share the following five characteristic traits:

1. Each occurs immediately after a distigme.

2. Each extends noticeably further into the margin than most bars adjacent to distigmai.

60 By the author's count $\mathrm{NA}^{28}$ 's apparatus contains only 168 multi-word variants in Matthew. Compared to the 5,343 Vaticanus lines in Matthew, this is fewer than one in 31.8 Vaticanus lines. Matthew is probably at the high end of how frequently multi-word variants occur because $\mathrm{NA}^{28}, 792-9$, lists more papyri of Matthew (twenty-four) than of any other NT book except John (thirty). Furthermore, variant readings due to harmonisation, which are often multi-word, are more frequent in the synoptic Gospels than any other part of the NT. Accordingly, five of the eight multi-word variants marked by distigme-obelos symbols are in the synoptic Gospels, two are from Matthew, and three are inter-synoptic harmonisations.

61 The two are Mark 14.70 (1301 B) and Acts 14.18 (1403 B). Both bars are short, only about $3 \mathrm{~mm}$ long, and neither extends much into the margin.

62 For the details of this chi-square test, see www.pbpayne.com/wp-content/uploads/2017/o1/ Vaticanus-distigme-obelos-chi-square.pdf.

63 There are 694 letters in the 42 lines of Vaticanus 1236 column A, Matthew's first column of narrative text, an average of 16.5 letters per line. 
3. Each is noticeably longer than most bars adjacent to distigmai.

4. Each occurs at the location of a widely recognised, multi-word addition.

5. A gap at the precise location of this addition follows all seven apparently original characteristic bars.

None of the other twenty bars adjacent to a distigme, which fulfils the first characteristic, shares more than two of the remaining four characteristics. Mere coincidence does not adequately explain the data.

All eight characteristic bars occur at the location of the same kinds of additions that scribe B marked with similarly shaped obeloi where the LXX added text to the MT. Since these eight characteristic horizontal bars are distinguishable in both form and function from paragraphoi, since their primary function of identifying the location of blocks of added text is the standard function of obeloi, and since this is not a function of paragraphoi, they should be recognised as obeloi. Since a distigme identifies a textual variant, and since an obelos identifies a specific category of textual variant, text that was added after the original composition, 'distigme-obelos' is the most appropriate name for this symbol. This conclusion is compatible with the possibility that some or all distigme-obelos symbols, as a secondary function, mark a paragraph break and that this may have influenced the obelos position.

\section{Why does Vaticanus Include the Added Text Only after the One Distigme-obelos in the Epistles and Never in the Gospels?}

1 Cor $14.34-5$, the text at the gap following the only distigme-obelos in the Vaticanus epistles, ${ }^{64}$ is the only added text marked by a distigme-obelos to be found in the Vaticanus text. Why is the added text here, but never in the Gospels? A satisfying answer comes from a surprising source. 'There is nothing apparently more "minor" or "trivial" than a mere dot, and yet matters of significance can depend on one. ${ }^{65}$ High stops hardly ever occur in the Vaticanus Gospels, but they mark the end of sentences throughout the Vaticanus epistles. ${ }^{66}$ Since scribe B copied both the Vaticanus Gospels and epistles, why this sharp contrast in use of high stops? The most natural explanation, and the only one congruent with a copyist's primary task, to reproduce the exemplar's text, is that the Gospels' exemplar(s) had virtually no high stops, but the epistles' exemplar(s)

64 See above, pp. 615-18.

65 Aland and Aland, The Text, 287.

66 P. Canart's 10 June 2013 email to the author states that he knows of no publication of this apparently original observation. C. Tischendorf, ed., Novum Testamentum Vaticanum post Angeli Maii aliorumque imperfectos labores ex ipso codice (Leipzig: Giesecke et Devrient, 1867) $\mathrm{xx}$-xxi notes that punctuation is much more frequent in the letters than in the Gospels but does not comment on its significance. 
used high stops extensively, and scribe B copied both exemplars faithfully enough to preserve this difference. Canart agrees with this explanation. ${ }^{67}$

The text of $\mathfrak{P}^{75}\left(\mathrm{NA}^{28}, 796\right.$, third century) is remarkably similar to the corresponding text of Vaticanus throughout Luke and John. ${ }^{68}$ Unlike the Vaticanus Gospels, however, $\mathfrak{P}^{75}$ uses high stops extensively. Like the Vaticanus Gospels, none of the NT papyri NA ${ }^{28}$ identifies as second-century $\left(P^{52}, \mathfrak{P}^{90}, \mathfrak{P}^{98}, \mathfrak{P}^{104}\right)$ contains a high stop. Metzger and Ehrman write, 'the earliest manuscripts have very little punctuation', ${ }^{69}$ and the Alands state, 'the original texts ... naturally also lacked punctuation' ${ }^{70}$ The lack of high stops in the Vaticanus Gospels, therefore, indicates a text even earlier than $\mathfrak{P}^{75}$ 's text. It corroborates both halves of Metzger's judgement: 'Since B is not a lineal descendent of $\mathfrak{P}^{75}$, the common ancestor of both carries the ... text to a period prior to $\mathrm{AD} 175^{-225}$, the date assigned to $\mathfrak{D}^{75} \cdot{ }^{71}$ It also supports Pisano's affirmation 'of the text of $\mathrm{B}$ as an extremely reliable witness ..., especially of the Gospels and Acts' ${ }^{72}$

The contrast in use of high stops between the Gospels and epistles in Vaticanus adds to other evidence that scribe B was careful to preserve the text of the Vaticanus exemplars. Only scribe B preserved obeloi and asterisks in the Vaticanus LXX text. As explained above (pp. 5-6), the original-ink ov $\varkappa^{\prime} \pi^{\prime}$ $\varepsilon \beta \rho^{\prime}$ ('is not in the Hebrew') where there are no obeloi in the prophetic books shows that scribe B did not even add obeloi to the exemplar's text. ${ }^{73}$ Scribe B preserved text its exemplars added both in the prophets and in 1 Cor 14.34-5, but marked these as later additions. In keeping with such faithful manuscript copying, it appears that scribe B faithfully copied the Vaticanus Gospels' exemplar with virtually no high stops but its epistles' exemplar with abundant high stops. This thesis, that scribe B faithfully copied a primitive text of the Gospels, explains both why the Vaticanus Gospels have virtually no high stops and why its text does not include any of the five blocks of added text its distigme-obelos symbols mark.

6710 June 2013 email to the author.

68 C. Martini, Il problema della recensionalità del codice B alla luce del papiro Bodmer XIV (AnBib 26; Rome: Pontificio Istituto Biblico, 1966) argues this in detail.

69 Metzger and Ehrman, The Text, 41.

70 Aland and Aland, The Text, 287.

71 B. Metzger, 'Recent Developments in the Textual Criticism of the New Testament', Historical and Literary Studies: Pagan, Jewish, and Christian (NTTS 8; Leiden/Grand Rapids: Brill/ Eerdmans, 1968) 145-62, at 157-8, building on Martini, Bodmer XIV, 181-3.

72 Pisano, 'The Text', 40. C. Stevens, 'Titus in $\mathfrak{D}^{32}$ and Sinaiticus: Textual Reliability and Scribal Design', Atlanta ETS Annual Meeting 18 Nov. 2015, found that $\mathfrak{P}^{32}\left(\mathrm{NA}^{28}, 793\right.$, 'ca. 200') and Sinaiticus differ in only one letter throughout their respective texts of Titus. Since scribes then copied entire collections of NT epistles, this indicates that the entire text of the epistles in Sinaiticus goes back at least to $c a$. 200. The Vaticanus Gospels combined with the Sinaiticus epistles apparently supply a second-century text of virtually the entire NT.

73 See above, pp. 608-9. 
The Vaticanus Gospels' text is so early that it preceded each of these five additions. $^{74}$

\section{Conclusion}

Distigmai in Vaticanus mark the location of Greek textual variants, as do some distigmai in the fourth- or fifth-century LXX G. Eight of the twenty-eight bars adjacent to distigmai are different from the other twenty in four respects:

1. They extend, on average, almost twice as far into the margin as the other twenty.

2. They are, on average, almost one third longer than the other twenty.

3. Each occurs at the location of a widely recognised, multi-word addition to the text.

4. All but one, with downward dipping strokes from both dots and the bar, indicating a different hand, ${ }^{75}$ have a gap in the following line at the precise location of the addition.

None of the other twenty bars shares both the first two graphic differences, and only two of the other twenty bars are at the location of a multi-word textual variant.

Seven key facts support the conclusion that all eight of these characteristic bars adjacent to a distigme are obeloi marking the location of a block of added text:

1. A multi-word textual variant in $\mathrm{NA}^{28}$, s apparatus occurs at all eight locations. If all eight were simply paragraphoi, this conjunction would have to be mere coincidence. The standard statistical test result rejects the coincidence hypothesis to a degree of probability over 500 times greater than the normal threshold needed to reject this hypothesis.

2. Scribe B left a gap at the exact location of a widely acknowledged block of added text following every characteristic bar, except one that is evidently from a different hand.

3. None of the other twenty bars adjacent to a distigme combines as much extension into the margin and total length as any of the eight characteristic bars.

4. Scribe B used horizontal-bar-form obeloi in the Vaticanus LXX prophets to mark the locations of blocks of added text. Only the original scribe could

74 Of course, this limited set does not imply that there are no blocks of added text in the Vaticanus Gospels. B. Metzger, A Textual Commentary on the Greek New Testament (Stuttgart: Deutsche Bibelgesellschaft, $1994^{2}$ ) 59, argues convincingly that Matt 27.49b in Vaticanus is added text.

75 See above, p. 614. 
have penned the obelos in the text of Isa 14.23, and explanations that obeloi mark added text contain original Vaticanus ink. These lines of evidence confirm that scribe B understood that obeloi mark added text.

5. The eight long characteristic bars adjacent to distigmai resemble the shape of the 117 long horizontal-bar-form obeloi attributed to scribe B in the Vaticanus prophets.

6. The obelos was the standard Greek symbol to mark added text.

7. Other NT manuscripts also use obeloi to mark blocks of added text, including John 7.53-8.11 and Mark's longer endings. ${ }^{76}$ Apparently, every manuscript with an obelos introducing Mark's longer ending notes that this ending is not 'in some of the copies'.

The name 'distigme-obelos' is ideal since it identifies the form of these symbols, a 'two dot-horizontal line', and their function, marking the location of blocks of added text. Their extension into the margin, on average, almost twice as far as the other twenty bars after distigmai, associates them with the adjacent distigme. The distigme-obelos symbols simply combine the Vaticanus standard distigme, marking the location of textual variants, with scribe B's favourite horizontal-bar-form obelos, specifying the variant is added text.

The virtually complete absence of high stops in the Vaticanus Gospels but their presence throughout the Vaticanus epistles and $\mathfrak{P}^{75}$ indicates that the text of the Vaticanus Gospels is earlier than the text of the Vaticanus epistles and of $\mathfrak{P}^{75}$. This explains why the only case where a distigme-obelos marks added text that is actually in the text of Vaticanus is in its epistles. The Vaticanus Gospels preserve a text so early, it is not contaminated by any of the five additions its distigme-obelos symbols mark.

These symbols give evidence scribe B was aware of variants, copied exemplars faithfully, and preferred the earliest possible text. Scribe B was extraordinarily careful not to add to or take away text from Vaticanus' exemplars, not even adding high stops or obeloi at some places where original ink marginal notes identify LXX additions to the MT. Scribe B identifies 1 Cor 14.34-5 as added text, ${ }^{77}$ but faithfully preserved those verses from the epistles' exemplar, just as scribe B faithfully preserved obelised text in the Vaticanus prophets. It is precisely because of this honesty with the textual data that scribe B's text-critical judgements should be respected, not dismissed. All this supports Birdsall's judgment, 'Behind the quality of the New Testament text in this codex, there appears to be critical "know-how". ${ }^{78}$ Since manuscripts confirm the accuracy of every

76 Cf. Metzger, Textual Commentary, 103, 189.

77 See above, pp. 615-18, and 621-2.

78 J. Birdsall, 'The Codex Vaticanus: Its History and Significance', The Bible as Book: The Transmission of the Greek Text (ed. S. McKendrick and O. O'Sullivan; London/New Castle, DE: British Library/Oak Knoll, 2003) 33-41, at 35. 
other one of scribe B's distigme-obelos text-critical judgements, one ought to assume that scribe B also had manuscript evidence that 1 Cor $14.34-5$ is added text. Indeed, scribe B evidently had access to far more early NT manuscript text than survives today. ${ }^{79}$

This is important theologically since the distigme-obelos at the interface of 1 Cor 14.33 and 34 provides a resolution to the notorious difficulty of reconciling vv. 34-5 with 1 Corinthians 11's inclusion of women prophesying and chapter 14's affirmations of 'all' prophesying: vv. 34-5 were not in Paul's original letter, but are a later addition. Therefore, Paul's unqualified affirmations of the equal standing of man and woman in Christ (Gal 3.28; Romans 16; Corinthians 7; 11.11-12) need not be qualified by vv. 34-5's huge caveat. Nor must one resort to exegetically implausible interpretations of vv. 34-5.

Just as critical editions use B" to designate Vaticanus' distigmai marking the locations of textual variants, ${ }^{80}$ this study recommends using $\mathrm{B}^{*}-$ to designate the eight distigme-obelos symbols marking added text. An appropriate apparatus entry for the omission of 1 Cor $14.34-5$ is: $o m$. B“ ${ }^{*} 88^{*}$ Fuldensis $^{\mathrm{mg}} \mathrm{Cl} \mathrm{TP}{ }^{81}$

79 See above, p. 615 and n. 38.

80 So Swanson, 1 Corinthians, 293-304; R. Swanson, New Testament Greek Manuscripts, Variant Readings Arranged in Horizontal Lines against Codex Vaticanus: 2 Corinthians (Carol Stream, IL/Pasadena, CA: Tyndale House/William Carey, 2005) 189-93.

$81 \mathrm{TP}$ = transcriptional probability. So Forte, 'Observations', 291; P. Payne, 'Ms. 88 as Evidence for a Text without 1 Cor 14.34-5', NTS 44 (1998) 152-8; Payne, 'Fuldensis', 240-50; Payne, Woman, 227-51. 